\title{
Influence of an extended education program on the knowledge of cardiovascular risk factors among subjects undergoing rehabilitation following acute coronary syndrome
}

\author{
Wojciech S. Kapko',2, Łukasz J. Krzych ${ }^{3,4}$ \\ ${ }^{1}$ Center for Research and Development, EMC Hospitals, John Paul II Geriatric Hospital, Katowice, Poland \\ ${ }^{2}$ Laboratory for Noninvasive Cardiovascular Diagnostics, SPZOZ Upper Silesian Rehabilitation Centre “Repty”, Tarnowskie Góry, \\ Poland \\ ${ }^{3}$ Chair and Clinic of Anesthesiology and Intensive Therapy, Medical University of Silesia, Katowice, Poland \\ ${ }^{4}$ Department of Cardiac Anesthesia and Intensive Care, Silesian Centre for Heart Diseases, Zabrze, Poland
}

Kardiochirurgia i Torakochirurgia Polska 2016; 13 (4): 386-392

\begin{abstract}
Introduction: Health education is a component of complex cardiac rehabilitation (CCR).

Aim: To evaluate the influence of an authorial extended educational program on the knowledge of cardiovascular risk factors among subjects undergoing early in-hospital rehabilitation following acute coronary syndrome treated with percutaneous intervention.

Material and methods: This prospective study covered 205 consecutive subjects (153 men and 52 women, aged $62 \pm 9$ years) undergoing CCR. They were randomly allocated to the control group (105 patients receiving standard education during CCR) or the study group (100 patients participating in the extended education program). The extended education program was conducted in the $2^{\text {nd }}$ and $3^{\text {rd }}$ week of CCR and included a package of educational materials and additional lectures.

Results: Knowledge of basic rules for secondary cardiac prevention was better in the study group, both on admission and after CCR. Notwithstanding, a positive influence of the extended educational program was found with regard to awareness of recommended blood pressure levels and blood lipid profile (improvement of $15-20 \%$ in the study group). At baseline, the knowledge of risk factors was comparable between the groups (the percentage of correct questionnaire answers was $50 \pm 17 \%$ among the controls vs. $49 \pm 16 \%$ in the study group; $p=0.77$ ), but improved significantly after education ( $52 \pm 17 \%$ among controls vs. $58 \pm 19 \%$ in the study group; $p=0.009$ ) and remained better in the study group after a 3-month follow-up ( $56 \pm 19 \%$ among controls vs. $64 \pm 19 \%$ in the study group).

Conclusions: Extended education during CCR significantly improves the knowledge of cardiovascular risk factors in patients after acute coronary syndrome.
\end{abstract}

Key words: complex cardiac rehabilitation, secondary prevention, cardiovascular risk, education.

\section{Streszczenie}

Wstęp: Edukacja zdrowotna jest jednym z elementów kompleksowej rehabilitacji kardiologicznej.

Cel: Ocena wpływu autorskiego, rozszerzonego programu edukacyjnego na wiedzę na temat czynników ryzyka sercowo-naczyniowego u pacjentów po ostrym incydencie wieńcowym, leczonych przezskórną angioplastyką, poddawanych wczesnej rehabilitacji kardiologicznej w warunkach stacjonarnych.

Materiat i metody: Prospektywną obserwacją objęto 205 kolejnych chorych (153 mężczyzn i 52 kobiety, w wieku $62 \pm 9$ lat) poddanych kompleksowej rehabilitacji kardiologicznej. Pacjentów podzielono losowo na grupę kontrolną (K, 105 osób poddanych standardowej edukacji) oraz badaną (B, 100 pacjentów poddanych rozszerzonemu programowi edukacyjnemu). Program edukacyjny przeprowadzono w 2. i 3. tygodniu rehabilitacji. Obejmowat on autorski pakiet materiałów edukacyjnych i dodatkowe wykłady.

Wyniki: Znajomość podstawowych zasad profilaktyki chorób układu krążenia wyjściowo i w obserwacji szpitalnej była lepsza w grupie B. Pozytywny wpływ programu edukacji stwierdzono w odniesieniu do znajomości rekomendowanych wartości ciśnienia tętniczego oraz określenia profilu lipidogramu (poprawa o 15-20\%). Wyjściowa wiedza na temat czynników ryzyka była podobna w obu grupach, a odsetek prawidłowych odpowiedzi wynosił $50 \pm 17 \%$ (grupa K) i $49 \pm 16 \%$ (grupa B) $(p=0,77$ ), jednak stała się ona znamiennie statystycznie lepsza po cyklu edukacji (K vs B: $52 \pm 17 \%$ vs $58 \pm 19 \%$; $p=0,009$ ) i pozostawała lepsza w obserwacji 3-miesięcznej (K vs B: $56 \pm 19 \%$ vs $64 \pm 19 \%$ ).

Wnioski: Rozszerzony program edukacji zdrowotnej prowadzonej podczas cyklu rehabilitacji znacząco poprawia wiedzę na temat czynników ryzyka sercowo-naczyniowego u chorych po ostrym incydencie wieńcowym.

Słowa kluczowe: kompleksowa rehabilitacja kardiologiczna, profilaktyka wtórna, ryzyko sercowo-naczyniowe, edukacja.

Address for correspondence: Wojciech S. Kapko, Center for Research and Development, EMC Hospitals, John Paul II, 31 Morawa St, 40-353 Katowice, Poland, phone: +48 502519 121, e-mail: wojtek_kapko@wp.pl

Received: 16.08.2016, accepted: 18.11.2016. 


\section{Introduction}

The main modifiable risk factors for cardiovascular diseases continue to include tobacco smoking, hypercholesterolemia, obesity, low physical activity, arterial hypertension, and diabetes [1]. Their early diagnosis and proper management constitute the fundamental elements of prevention, which translates into a significant reduction in mortality due to cardiovascular causes (even up to 50-75\%) [2, 3].

Population-based prevention and health education programs are meant to serve as an effective source of reliable information on health and its determinants. They are particularly important for individuals after previous coronary incidents because they translate into improved prognosis $[1,4]$. In order to assess the implementation of rules for circulatory disease prevention into everyday practice, both national and international multicenter epidemiological studies are being systematically conducted [5-8]. Their results underscore the still excessively high incidence of modifiable cardiovascular risk factors and their insufficient control. This state of affairs is attributed to the poor effectiveness of the public health sector's actions on the one hand, and the reluctance of patients to broaden their knowledge on the topic or participate in rehabilitation programs after discharge on the other [9].

Thus, it seems justified to pose the question whether extending the education provided during comprehensive cardiac rehabilitation (CCR) cycles $[10,11]$ improves the knowledge of cardiovascular risk factors. After all, it is known that participants of rehabilitation programs are much more enthusiastic with regard to expanding their knowledge on the topic $[12,13]$ and that the favorable effect persists in long-term follow-up [14, 15].

\section{Aim}

The aim of the study was to assess the influence of the described authorial education program on the awareness of cardiovascular risk factors among patients after acute coronary incidents treated with percutaneous angioplasty and undergoing early in-hospital cardiac rehabilitation.

\section{Material and methods}

The prospective study included 205 subsequent patients who were hospitalized at the Upper Silesian Rehabilitation Center "Repty" as part of early in-hospital cardiac rehabilitation between May 2013 and April 2014 after suffering acute coronary incidents and being treated with transcutaneous angioplasty. Patients who qualified for comprehensive cardiac rehabilitation were included in the study [10]. The exclusion criteria were: physical disability preventing the patient from participating in the rehabilitation procedures (e.g. amputations, advanced osteoarthritis, poorly controlled obstructive pulmonary disease), disability preventing the patient from filling out the questionnaire or using the educational materials (e.g. significant amblyopia despite vision correction), mental disability preventing the patient from filling out the questionnaire, significant systemic diseases (e.g., systemic connective tissue diseases, neoplastic disease), incomplete rehabilitation cycle, and lack of consent. The patients were randomly assigned to one of two groups: 105 patients received standard education during the rehabilitation cycle (controls), while 100 patients participated in an extended education program (study group).

Standard education involved a weekly 45-minute lecture. The education program was conducted during the $2^{\text {nd }}$ and $3^{\text {rd }}$ weeks of rehabilitation and included an authorial package of educational materials prepared in accordance with the guidelines of the Polish Forum for Prevention [16], materials from the educational campaign of the Polish Cardiac Society "Nie zawal! Wybierz życie" (www.niezawal.pl) received in agreement with the Astra Zeneca company, and two additional 45-minute lectures (educator: a Partner of the Polish Forum for Prevention).

The research tool was the original questionnaire developed based on the "Guidelines Polish Forum of Cardiovascular Prevention" (Annex). Additional information was obtained from the available medical records and structured interviews conducted at admission. Before being deployed, the questionnaire was validated (the $\kappa$ statistic ranged from 0.82 to 1.0). The patients filled out the form at the beginning (time ' 0 ') and toward the end of the rehabilitation cycle (time ' 1 '). Additionally, the questionnaire was sent to 50 randomly selected individuals from both groups 3 months after the end of rehabilitation (time ' 2 '). The participation rate in both groups during the rehabilitation program was $100 \%$; the rate of return for the questionnaires that were sent by mail was $26 \%$ in the study group and $32 \%$ among the controls. Due to this low participation rate and a risk of bias, the data from the 3-month follow-up were excluded from statistical comparisons.

The project was not a medical experiment and did not require approval of an ethics committee.

\section{Statistical analysis}

Statistical analysis was conducted based on procedures contained within SAS v.9.4 software (SAS Institute Inc. Cary, North Carolina, USA). To describe quantitative variables, the mean values and their standard deviations were calculated, and distribution normality was verified with the Kolmogorov-Smirnov test. Qualitative variables were presented as absolute values and percentages. Correlations between quantitative variables were assessed based on the value of Pearson's correlation coefficient, while variables with non-normal distribution underwent logarithmic transformation. To evaluate intergroup differences in quantitative variables, we used Student's $t$-test (for variables meeting the criteria for normal distribution) or its nonparametric equivalent - the Mann Whitney $U$-test (when the distribution was not normal). A t-test for paired variables or its nonparametric equivalent was used for paired variables; in the case of qualitative variables, a $\chi^{2}$ test or McNemar's test was used. In order to interpret the obtained differences and relationships, the criterion of statistical significance was set at $p<0.05$. 
Influence of an extended education program on the knowledge of cardiovascular risk factors among subjects undergoing rehabilitation following acute coronary syndrome

Tab. I. Patient characteristics

\begin{tabular}{lccc} 
Variable & Controls & Study group & P-value \\
Male gender & $73(70 \%)$ & $80(80 \%)$ & 0.08 \\
\hline Age $[$ years] & $62 \pm 9$ & $62 \pm 10$ & 0.65 \\
\hline $\mathrm{BMI}\left[\mathrm{kg} / \mathrm{m}^{2}\right]$ & $29 \pm 4$ & $28 \pm 4$ & 0.07 \\
\hline Overweight or obesity $\left(\mathrm{BMI} \geq 25 \mathrm{~kg} / \mathrm{m}^{2}\right)$ & $89(85 \%)$ & $70(70 \%)$ & 0.01 \\
\hline Obesity $\left(\mathrm{BMI} \geq 30 \mathrm{~kg} / \mathrm{m}^{2}\right)$ & $39(37 \%)$ & $33(33 \%)$ & 0.44 \\
\hline Nicotinism & $62(59 \%)$ & $9(9 \%)$ & $<0.01$ \\
\hline Nicotinism - pack-years & $15 \pm 4$ & $16 \pm 4$ & 0.53 \\
\hline Low physical activity $($ declared) & $10(10 \%)$ & $13(13 \%)$ & 0.57 \\
\hline Arterial hypertension & $83(79 \%)$ & $71(71 \%)$ & 0.18 \\
\hline Diabetes & $34(33 \%)$ & $21(21 \%)$ & 0.07 \\
\hline Dyslipidemia & $62(59 \%)$ & $38(38 \%)$ & $<0.01$ \\
\hline Family history of cardiovascular diseases & $65(62 \%)$ & $62(62 \%)$ & 0.89 \\
\hline
\end{tabular}

WHR - waist-to-hip ratio.

Tab. II. Knowledge of one's own cardiovascular risk factors in both groups at baseline and after the education program

\begin{tabular}{|c|c|c|c|c|c|c|}
\hline \multirow[t]{2}{*}{ Risk factor } & \multicolumn{3}{|c|}{ Controls } & \multicolumn{3}{|c|}{ Study group } \\
\hline & ‘0’ & '1' & '2' & ‘ 0 ' & '1' & '2' \\
\hline Body mass & 103 (98\%) & 103 (98\%) & 15 (94\%) & 98 (98\%) & $92(92 \%)^{\star}$ & $13(100 \%)$ \\
\hline Arterial pressure & 67 (64\%) & $67(64 \%)$ & $15(94 \%)$ & $84(84 \%)^{*}$ & $84(84 \%)^{*}$ & $10(77 \%)$ \\
\hline Glycemia & $43(41 \%)$ & $43(41 \%)$ & $12(75 \%)$ & $60(60 \%)^{*}$ & $60(60 \%)^{*}$ & $10(77 \%)$ \\
\hline Cholesterol concentration & 34 (33\%) & 34 (33\%) & $14(88 \%)$ & $48(48 \%)^{*}$ & $51(51 \%)^{*}$ & $9(69 \%)$ \\
\hline
\end{tabular}

${ }^{*} p<0.05$ study group vs. controls.

Tab. III. Knowledge of the basic rules for the prevention of cardiovascular diseases in both groups at baseline and after the education program

\begin{tabular}{|c|c|c|c|c|c|c|}
\hline \multirow[t]{2}{*}{ Prevention rule } & \multicolumn{3}{|c|}{ Control group } & \multicolumn{3}{|c|}{ Study group } \\
\hline & '0’ & '1' & '2' & '0' & ' 1 ' & '2' \\
\hline Normal arterial blood pressure & $10(10 \%)$ & $10(10 \%)$ & $4(25 \%)$ & $30(30 \%)^{*}$ & $35(35 \%)^{* * * *}$ & $6(38 \%)$ \\
\hline Normal glycemia & $50(48 \%)$ & $50(48 \%)$ & $9(56 \%)$ & $39(39 \%)$ & $39(39 \%)$ & $6(38 \%)$ \\
\hline Normal cholesterol concentration & $69(68 \%)$ & $69(68 \%)$ & $7(43 \%)$ & $32(32 \%)^{*}$ & $34(34 \%)^{*}$ & $4(25 \%)$ \\
\hline The concept of HDL & $34(32 \%)$ & $34(32 \%)$ & $10(62 \%)$ & $53(53 \%)^{*}$ & $62(62 \%)^{* \star * *}$ & $6(38 \%)$ \\
\hline The concept of LDL & $34(32 \%)$ & $34(32 \%)$ & $10(62 \%)$ & $54(54 \%)^{\star}$ & $68(68 \%)^{*, * *}$ & $6(38 \%)$ \\
\hline Normal recommended physical activity & 87 (83\%) & 87 (83\%) & $1(6 \%)$ & $6(6 \%)^{\star}$ & $7(7 \%)^{*}$ & 0 \\
\hline
\end{tabular}

${ }^{*} p<0.05$ study group vs. controls; ** $p<0.05$ after the rehabilitation cycle (' 1 ') vs. baseline ('0').

\section{Results}

The study analyzed 205 patients (153 men and 52 women) at the mean age of $62 \pm 9$ years. Patient characteristics and intergroup differences are presented in Table I. Parameters that were statistically significantly more frequent among the controls included: overweight (but not obesity), tobacco addiction (though the number of pack-years was similar), and dyslipidemia. Patients from the study group were less likely to know their body mass value, but were more often aware of arterial pressure, glycemia, and cholesterol concentration (Tab. II).

The study group also showed better awareness of the fundamental rules for the prevention of cardiovascular diseases, both at baseline and during follow-up (Tab. III). The education program also improved the knowledge of recommended arterial pressure values and lipid profiles (Tab. III).
At baseline, the knowledge of risk factors was similar in both groups, and the percentage of correct answers was 50 $\pm 17 \%$ among the controls and $49 \pm 16 \%$ in the study group $(p=0.77$ ) (Fig. $1 \mathrm{~A})$, but it became statistically significantly better after the education cycle (52 $\pm 17 \%$ among controls vs. $58 \pm 19 \%$ in the study group; $p=0.009$ ) (Fig. 1 B) and remained better during the 3-month follow-up (56 $\pm 19 \%$ among controls vs. $64 \pm 19 \%$ in the study group) (Fig. 1 C). The largest improvement in risk factor awareness (by over $60 \%$ ) was noted with regard to the associations between cardiovascular diseases and male gender, fat consumption, lack of physical activity, family history of stroke, and low HDL concentration (Tab. IV). Even after the education cycle, some of the patients were unable to answer whether osteoporosis, depression, and tall height are associated with cardiovascular diseases. 

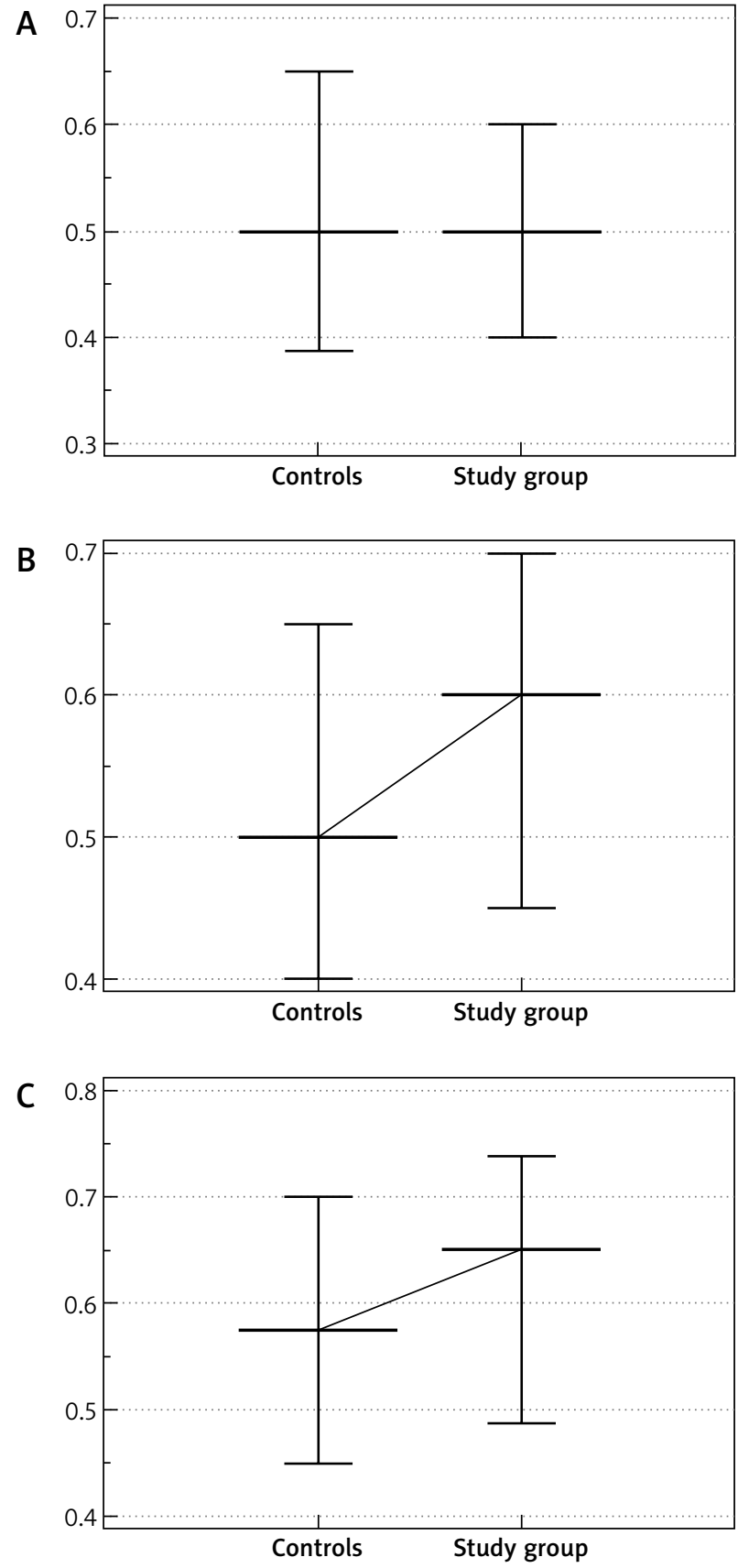

Fig. 1. Knowledge about cardiovascular risk factors. Percentages of correct questionnaire answers: baseline (A), after education (B), and after a 3-month follow-up (C)

\section{Discussion}

Many studies document the lack of a significant relationship between being burdened with cardiovascular risk and being aware of the danger it poses or the ways in which it can be limited by controlling the modifiable determinants $[14,17,18]$. The issue is particularly relevant in individuals after acute coronary syndrome treated with transcutaneous interventions. The disease and its consequences (sudden death, heart failure, cardiac dysrhythmias, etc.) are often underestimated by the patients as the
Tab. IV. Influence of the education program on patient awareness with regard to specific cardiovascular risk factors

\begin{tabular}{lccc} 
Is the factor & \multicolumn{3}{c}{ Correct answers } \\
a cardiovascular & Baseline & $\begin{array}{c}\text { After } \\
\text { education }\end{array}$ & $\begin{array}{c}\text { 3-month } \\
\text { follow-up }\end{array}$ \\
\cline { 2 - 4 } Excess body mass & $93(93 \%)$ & $93(93 \%)$ & $13(100 \%)$ \\
\hline Older age & $42(42 \%)$ & $45(45 \%)$ & $8(62 \%)$ \\
\hline Osteoporosis & $35(35 \%)$ & $31(31 \%)$ & $6(46 \%)$ \\
\hline Male gender & $18(18 \%)$ & $29(29 \%)$ & $5(38 \%)$ \\
\hline Tall height & $44(44 \%)$ & $38(38 \%)$ & $8(62 \%)$ \\
\hline Consuming vegetable fats & $25(25 \%)$ & $41(41 \%)$ & $6(46 \%)$ \\
\hline Arterial hypertension & $77(77 \%)$ & $88(88 \%)$ & $13(100 \%)$ \\
\hline Physical exercise & $27(27 \%)$ & $54(54 \%)$ & $8(62 \%)$ \\
\hline Cigarette smoking & $92(92 \%)$ & $93(93 \%)$ & $12(92 \%)$ \\
\hline Pipe smoking & $70(70 \%)$ & $76(76 \%)$ & $10(77 \%)$ \\
\hline Diabetes & $69(69 \%)$ & $75(75 \%)$ & $7(54 \%)$ \\
\hline Ulcer disease & $28(28 \%)$ & $37(37 \%)$ & $6(46 \%)$ \\
\hline $\begin{array}{l}\text { High cholesterol } \\
\text { concentration }\end{array}$ & $76(76 \%)$ & $83(83 \%)$ & $11(85 \%)$ \\
\hline Low HDL cholesterol & $17(17 \%)$ & $30(30 \%)$ & $3(23 \%)$ \\
\hline concentration & $74(74 \%)$ & $82(82 \%)$ & $12(92 \%)$ \\
\hline Chronic stress & $8(8 \%)$ & $11(11 \%)$ & 0 \\
\hline Symptoms of depression & $35(35 \%)$ & $49(49 \%)$ & $8(62 \%)$ \\
\hline Environmental pollution & $69(69 \%)$ & $77(77 \%)$ & $13(100 \%)$ \\
\hline $\begin{array}{l}\text { Family history of heart } \\
\text { disease }\end{array}$ & $64(64 \%)$ & $81(81 \%)$ & $11(85 \%)$ \\
\hline Lack of physical activity & $22(22 \%)$ & $44(44 \%)$ & $6(46 \%)$ \\
\hline Family history of stroke & & & \\
\hline & & & \\
\hline
\end{tabular}

provided treatment is quick, safe, and effective [19, 20]. Some patients equate the abatement of angina symptoms with being cured, which can make counseling concerning secondary prevention (pharmacological and non-pharmacological) especially challenging. In the meantime, over half of coronary patients are burdened with several risk factors, mostly excessive body mass, hypertension, dyslipidemia, tobacco addiction, abnormal carbohydrate tolerance, or metabolic syndrome [19]. Therefore, various interventions are undertaken to promote cardiovascular risk awareness, which is only the first step but a key one in improving prevention. This includes cardiac rehabilitation, educational training in the work environment at basic and specialist healthcare facilities, as well as community programs and media campaigns addressed to patients and their families. As the effectiveness of these actions remains varied [2126], the search for better solutions continues.

Our project has demonstrated that extending the education program provided during in-hospital CCR improves the knowledge of cardiovascular risk factors by as much as $20 \%$, a benefit which may persist for several weeks after discharge (although our ability to draw conclusions in this regard was rather limited by the low participation rate). Most improvement was noted with regard to the best known risk 
factors (gender, diet, physical activity, family history), which probably means that the training cycle helped the patients remember the knowledge that they had previously acquired and forgotten. These observations are in line with reports both from Poland and abroad. Even standard education provided during CCR improves patient awareness significantly, as demonstrated by Deskur-Śmielecka et al. The researchers noted the largest improvement with regard to selected elements of diet, the knowledge of one's own arterial pressure, and the knowledge of the recommended arterial pressure values. The effect is usually long-lasting and persists for several months after the rehabilitation $[12,15]$, especially with regard to tobacco addiction, dietary recommendations, and physical activity. The effect of longer and more comprehensive education programs can be several times better [27, 28].

The present study has a few limitations. Firstly, the project was conducted at a single center, with limited options to extrapolate the results to other populations. Secondly, it cannot be excluded that individuals participating in in-hospital rehabilitation are characterized by completely different levels of knowledge and approach to education than individuals undergoing out-patient rehabilitation; therefore, the results in the latter group could be completely different. Thirdly, our statistical analysis did not include the role of confounders such as education, occupational status, socio-economic profile, or psychological factors, which can influence the selfawareness of patients or their willingness to improve their knowledge (e.g., women, individuals with higher education, and individuals free from depression are typically more willing to learn). Finally, the project was innovative and authorial despite being based on generally known recommendations. It was not, however, individualized, i.e., customized to the cognitive and intellectual levels of each participant and to their individual cardiovascular risk. In the meantime, it has been demonstrated that standard programs addressed to the general population of patients undergoing rehabilitation should be replaced with individualized programs including counseling for specific patients. Even if the training is shorter, the patients will benefit more from education focusing specifically on how they can control the modifiable factors, and the effect will be longer lasting.

\section{Conclusions}

The extended health education program conducted during a cycle of in-hospital rehabilitation significantly improved the knowledge of cardiovascular risk factors among patients treated with transcutaneous interventions after acute coronary incidents.

\section{Disclosure}

Authors report no conflict of interest.

\section{References}

1. Authors/Task Force Members, Piepoli MF, Hoes AW, Agewall S, Albus C, Brotons C, Catapano AL, Cooney MT, Corrà U, Cosyns B, Deaton C, Graham I, Hall MS, Hobbs FD, Løchen ML, Löllgen H, Marques-Vidal P, Perk J, Prescott E, Redon J, Richter DJ, Sattar N, Smulders Y, Tiberi M, van der Worp HB, van Dis I,
Verschuren WM; Additional Contributor: Simone Binno (Italy); Document Reviewers:, De Backer G, Roffi M, Aboyans V, Bachl N, Bueno H, Carerj S, Cho L, Cox J, De Sutter J, Egidi G, Fisher M, Fitzsimons D, Franco OH, Guenoun M, Jennings C, Jug B, Kirchhof P, Kotseva K, Lip GY, Mach F, Mancia G, Bermudo FM, Mezzani A, Niessner A, Ponikowski P, Rauch B, Rydén L, Stauder A, Turc G, Wiklund O, Windecker S, Zamorano JL. 2016 European Guidelines on cardiovascular disease prevention in clinical practice: The Sixth Joint Task Force of the European Society of Cardiology and Other Societies on Cardiovascular Disease Prevention in Clinical Practice (constituted by representatives of 10 societies and by invited experts): Developed with the special contribution of the European Association for Cardiovascular Prevention \&amp; Rehabilitation (EACPR). Eur J Prev Cardiol 2016; 23: NP1-NP96.

2. Palmieri L, Bennett K, Giampaoli S, Capewell S. Explaining the decrease in coronary heart disease mortality in Italy between 1980 and 2000. Am J Public Health 2010; 100: 684-692.

3. Bandosz P, O'Flaherty M, Drygas W, Rutkowski M, Koziarek J, Wyrzykowski B, Bennett K, Zdrojewski T, Capewell S. Decline in mortality from coronary heart disease in Poland after socioeconomic transformation: modelling study. BMJ 2012; 344: d8136.

4. Fernandez R, Griffiths R, Everett B, Davidson P, Salamonson Y, Andrew S. Effectiveness of brief structured interventions on risk factor modification for patients with coronary heart disease: a systematic review. Int J Evid Based Healthc 2007; 5: 370-405.

5. Zdrojewski T, Wyrzykowski B, Wierucki L, Grodzicki T, Januszewicz A, Narkiewicz K, Zarzeczna-Baran M, Gluszek J, Opolski G, Zatonski W, Tykarski A, Drygas W. Attempt to eliminate health inequalities in Poland arising at the time of political and economic transformation: Polish 400 Cities Project. Eur J Cardiovasc Prev Rehabil 2006; 13: 832-838.

6. Bielecki W, Kaczmarczyk-Chałas K, Piwońska A, Kozakiewicz K, Głuszek J, Biela U, Zdrojewski T, Piotrowski W. Awareness of guidelines for cardiovascular disease prevention among the adult population in Poland. Results of the WOBASZ program. Kardiol Pol 2005; 63 (6 Suppl 4): S677-S681.

7. De Backer G, De Bacquer D, Rydén L, Kotseva K, Gaita D, Georgiev B, Gotcheva N, Mancas S, Miličić D, Pająk A, Reiner Ž, Wood D; EUROASPIRE investigators. Lifestyle and risk factor management in people at high cardiovascular risk from Bulgaria, Croatia, Poland, Romania and the United Kingdom who participated in both the EUROASPIRE III and IV primary care surveys. Eur J Prev Cardiol 2016; 23: 1618-1627.

8. Kotseva K, De Bacquer D, Jennings C, Gyberg V, De Backer G, Rydén L, Amouyel P, Bruthans J, Cifkova R, Deckers JW, De Sutter J, Fraz Z, Graham I, Keber I, Lehto S, Moore D, Pajak A, Wood D; EUROASPIRE Investigators. Time trends in lifestyle, risk factor control, and use of evidence-based medications in patients with coronary heart disease in Europe: results from 3 EUROASPIRE Surveys, 1999-2013. Glob Heart 2016 Mar 16. pii: S2211-8160(15)00295-1. doi: 10.1016/j.gheart.2015.11.003.

9. Neubeck L, Freedman SB, Clark AM, Briffa T, Bauman A, Redfern J. Participating in cardiac rehabilitation: a systematic review and meta-synthesis of qualitative data. Eur J Prev Cardiol 2012; 19: 494-503.

10. Dylewicz P, Jegier A, Piotrowicz R, Rudnicki S, Tylka J, Mazurek K, Przywarska I, Rybicki J, Zdrojewski T. Kompleksowa Rehabilitacja Kardiologiczna. Stanowisko Komisji ds. Opracowania Standardów Rehabilitacji Kardiologicznej Polskiego Towarzystwa Kardiologicznego. Folia Cardiologica 2004; 11 (Supl. A): A1-A48.

11. Jankowski P, Niewada M, Bochenek A, Bochenek-Klimczyk K, Bogucki M, Drygas W, Dudek D, Eysymontt Z, Grajek S, Kozierkiewicz A, Mamcarz A, Olszowska M, Pająk A, Piotrowicz R, Podolec P, Wolszakiewicz J, Zdrojewski T, Zielińska D, Opolski G, Stępińska J. Optimal model of comprehensive rehabilitation and secondary prevention. Kardiol Pol 2013; 71: 995-1003.

12. Cottin Y, Cambou JP, Casillas JM, Ferrières J, Cantet C, Danchin N. Specific profile and referral bias of rehabilitated patients after an acute coronary syndrome. J Cardiopulm Rehabil 2004; 24: 38-44.

13. Redfern J, Ellis ER, Briffa T, Freedman SB. High risk-factor level and low riskfactor knowledge in patients not accessing cardiac rehabilitation after acute coronary syndrome. Med J Aust 2007; 186: 21-25.

14. Fernandez RS, Salamonson Y, Griffiths R, Juergens C, Davidson P. Awareness of risk factors for coronary heart disease following interventional cardiology procedures: a key concern for nursing practice. Int J Nurs Pract 2008; 14: 435-442.

15. Griffo R, Ambrosetti M, Tramarin R, Fattirolli F, Temporelli PL, Vestri AR, De Feo S, Tavazzi L; ICAROS investigators. Effective secondary prevention through cardiac rehabilitation after coronary revascularization and predictors of poor adherence to lifestyle modification and medication. Results of the ICAROS Survey. Int J Cardiol 2013; 167: 1390-1395. 
16. Polskie Forum Profilaktyki Chorób Układu Krążenia. Dostęp: http://www.pfp. edu.pl/index.php?id=wytyczne

17. Kayaniyil S, Ardern Cl, Winstanley J, Parsons C, Brister S, Oh P, Stewart DE, Grace SL. Degree and correlates of cardiac knowledge and awareness among cardiac inpatients. Patient Educ Couns 2009; 75: 99-107.

18. Nolan MT, McKee G. Is knowledge level of coronary heart disease and risk factors among post-percutaneous coronary intervention patients adequate? J Cardiovasc Nurs 2016; 31: E1-E9.

19. Kirkland SA, MacLean DR, Langille DB, Joffres MR, MacPherson KM, Andreou P. Knowledge and awareness of risk factors for cardiovascular disease among Canadians 55 to 74 years of age: results from the Canadian Heart Health Surveys, 1986-1992. CMAJ 1999; 161 (8 Suppl): S10-S16.

20. Perk J, Hambraeus K, Burell G, Carlsson R, Johansson P, Lisspers J. Study of Patient Information after percutaneous Coronary Intervention (SPICl): should prevention programmes become more effective? Eurolntervention 2015; 10: e1-e7.

21. Brown JP, Clark AM, Dalal H, Welch K, Taylor RS. Effect of patient education in the management of coronary heart disease: a systematic review and meta-analysis of randomized controlled trials. Eur J Prev Cardiol 2013; 20: 701-714.

22. Müller-Riemenschneider F, Damm K, Meinhard C, Bockelbrink A, Vauth C, Willich SN, Greiner W. Evaluation of medical and health economic effectiveness of non-pharmacological secondary prevention of coronary heart disease. GMS Health Technol Assess 2009; 5: Doc16. doi: 10.3205/hta000078.
23. Anderson L, Thompson DR, Oldridge N, Zwisler AD, Rees K, Martin N, Taylor RS. Exercise-based cardiac rehabilitation for coronary heart disease. Cochrane Database Syst Rev 2016; 1: CD001800.

24. Fernandez R, Griffiths R, Everett B, Davidson P, Salamonson Y, Andrew S. Effectiveness of brief structured interventions on risk factor modification for patients with coronary heart disease: a systematic review. Int J Evid Based Healthc 2007; 5: 370-405.

25. Crouch R, Wilson A, Newbury J. A systematic review of the effectiveness of primary health education or intervention programs in improving rural women's knowledge of heart disease risk factors and changing lifestyle behaviours. Int J Evid Based Healthc 2011; 9: 236-245.

26. Deskur-Smielecka E, Borowicz-Bieńkowska S, Przywarska I, Brychcy A, Dylewicz P. Knowledge of cardiovascular risk factors and recommended lifestyle modifications in patients after an acute coronary syndrome. The influence of short-term, stationary rehabilitation. Preliminary results. Kardiol Pol 2008; 66: 230-232.

27. McKinley S, Dracup K, Moser DK, Riegel B, Doering LV, Meischke H, Aitken LM, Buckley T, Marshall A, Pelter M. The effect of a short one-on-one nursing intervention on knowledge, attitudes and beliefs related to re sponse to acute coronary syndrome in people with coronary heart disease: a randomized controlled trial. Int J Nurs Stud 2009; 46: 1037-1046.

28. Redfern J, Briffa T, Ellis E, Freedman SB. Choice of secondary prevention improves risk factors after acute coronary syndrome: 1-year follow-up of the CHOICE (Choice of Health Options In prevention of Cardiovascular Events) randomised controlled trial. Heart 2009; 95: 468-475. 


\section{Annex}

Dear patient, QUESTIONNAIRE 1

We invite you to complete the questionnaire below; it will allow us to assess your knowledge concerning the basic risk factors that directly influence cardiac diseases. Please remember: this is not an exam or a test, and the results will not influence your treatment!

Name and surname:.

Body mass: $\quad$....................... kg I don't know $\square$

Height: $\quad$..................... kg I don't know $\square$

\section{Education:}

Primary or occupational

Secondary

Post-secondary

Incomplete higher education or B.A

Higher

Do you know the level of YOUR:

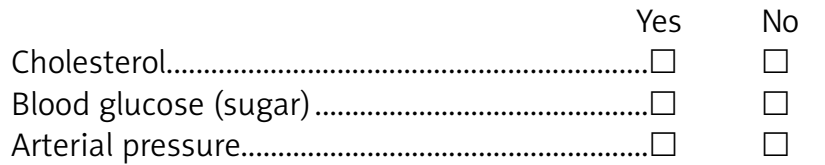

Normal cholesterol concentration is lower than (please select one answer)
A. $300 \mathrm{mg} / \mathrm{dl}$
B. $250 \mathrm{mg} / \mathrm{dl}$
C. $200 \mathrm{mg} / \mathrm{dl}$
D. $150 \mathrm{mg} / \mathrm{dl}$
E. The lower, the better
F. I don't know

Normal fasting blood glucose (sugar) concentration is lower than (please select one answer)
A. $200 \mathrm{mg} / \mathrm{dl}$
B. $150 \mathrm{mg} / \mathrm{dl}$
C. $126 \mathrm{mg} / \mathrm{dl}$
D. $100 \mathrm{mg} / \mathrm{dl}$
E. The lower, the better
F. I don't know

Normal arterial blood pressure is lower than (please select one answer)
A. $130 / 95 \mathrm{~mm} \mathrm{Hg}$
B. $140 / 90 \mathrm{~mm} \mathrm{Hg}$
C. $150 / 80 \mathrm{~mm} \mathrm{Hg}$
D. $150 / 90 \mathrm{~mm} \mathrm{Hg}$
E. The lower, the better
F. I don't know

Do you know the following concepts:

"Bad" cholesterol

"Good" cholesterol

"Bad" cholesterol is:
A. LDL cholesterol
B. HDL cholesterol

C. Total cholesterol

D. I don't know

"Good" cholesterol is:

A. LDL cholesterol

B. HDL cholesterol

C. Total cholesterol

D. I don't know

Please describe your physical activity:

Very low $\square$ Low $\square$ Moderate $\square$ High $\square$ Very high $\square$

Please describe your physical condition:

Very low $\square$ Low $\square$ Moderate $\square$ High $\square$ Very high $\square$

How much physical activity is required to stay healthy? (please select one answer)

A. 30 minutes, every day

B. 30 minutes, more than 3 times per week

C. 30 minutes, at least once per week

D. 30 minutes, once per week

E. The more activity, the better

F. I don't know

Has anyone in your immediate family suffered from a heart disease?

A. Husband/wife

B. Son/daughter

C. Mother/father

D. Brother/sister

E. No

F. I don't know

Please select risk factors which can result in MYOCARDIAL INFARCTION:

Yes No I don't

- Overweight

- Older age.

- Osteoporosis

- Male gender.

- Tall height.....

- Consuming vegetable fats.

- Arterial hypertension.

- Physical work..

- Cigarette smoking

- Pipe smoking.

- Diabetes.

- Ulcer disease..

- High cholesterol

- Low HDL cholesterol.

- Chronic stress

- Frequent depression.

- Environmental pollution

- Family history of heart disease.

- Lack of physical activity..

- Family history of stroke...

That is all. Thank you! 